Article

\title{
The Implementation of Green Infrastructure: Relating a General Concept to Context and Site
}

\author{
Gunilla Lindholm \\ Department of Urban and Rural Development, Swedish University of Agricultural Sciences, \\ 75007 Uppsala, Sweden; gunilla.lindholm@slu.se; Tel.: +46-702-108750 \\ Academic Editor: Davide Geneletti \\ Received: 10 January 2017; Accepted: 10 April 2017; Published: 14 April 2017
}

\begin{abstract}
In the quest for more sustainable urban landscape development, the concept of "green infrastructure" (GI) has become central in policy documents and as a multifunctional general planning tool. GI is not, however, a simple and unambiguous solution. While in policy documents there are claims for more and connected GI, actual urban development takes another direction. The densifying imperative is hard to combine with an increased and more connected GI. This paper argues for a critical and diversified approach to the concept of GI, in order to facilitate its implementation in urban planning and management. Any kind of GI will not deliver all ecosystems services in any place, not without land use conflicts, investments and long term operating costs. This calls for a GI concept linked to actors and mediating conflicting values. Linguistic as well as spatial definitions of the two relevant dichotomies of "green-grey" and "public-private" are crucial in GI location, design, construction and management, it is argued. Overarching representations of GI will be needed, but not only pictured as a separate system, but also displayed with necessary integration to the whole urban landscape. Development over time will need an intersectorial implementation and management program. Some of the GI intentions may be implemented in planning processes, some through re-organization and redesign of public space, and some by agreements with landowners. To reach out to implementation in ordinary urban development, GI needs to be described in a way that establishes points of connection to a variety of relevant actors and organizations taking part in implementation of GI.
\end{abstract}

Keywords: green infrastructure; sustainable urban development; urban planning; landscape representations

\section{The Versatile Discourse on Green Infrastructure-Benefits and Obstacles}

The discourse on green infrastructure (GI), is multifaceted and sometimes ambiguous [1-10]. Definitions may appear similar enough:

... an interconnected network of green space that conserves natural ecosystem values and functions and provides associated benefits to human populations [11].

... strategic planning approach that aims at developing networks of green and blue spaces in urban areas designed and managed to deliver a wide range of ecosystem services [12].

Yet the quotations show a change of focus over time. Thirteen years have passed (2002-2015) between these definitions and while the former represents research on the functions and benefits of GI, as well as the network necessary to "conserve(s) natural ecosystem values" [11], the latter represents the more recent trend to develop green and blue spaces "designed and managed to deliver a wide range of ecosystem services" [12]. Although these definitions do not contradict each other (you may rather see the first encapsulated in the second) they mirror not only a displacement from "conserve" to "develop", 
but also an overall change in context. While the urban planning trend in the twentieth century was that of sprawl, the current imperative for planning offices is urban densification (while sprawl seems unhampered). Within a densified situation, there is certainly a need for solid knowledge on how to plan and construct GI to deliver ecosystem services. A question remains, however, about in what way (if any) this new knowledge is used in order to alter or even question a densification process, within the foregoing planning and governance deliberations. Can we call anything a "strategic planning approach" which does not question other (more powerful) strategic planning approaches? On the other hand, the inclusion of design and management of green areas clarifies that GI is not only a question of network structuring, but also of the multivalent function of each of the parts. Hence, the discourse on GI has developed; it has estranged itself from a conservatism connected to "natural ecosystem values" and approached the more constructivist mindsets of contemporary urban development. Yet there is in this knowledge building process a risk of "leaving behind" the facticity of GI. Each of the GI values is both a site property and an effect of a system and the multivalence is not possible to extract from the system alone. When the GI concept is transferred from "the green sectors" where this knowledge is imbued (such as urban ecology, urban forestry, landscape architecture and park management) to the urban planning realm and the political decisions for urban development, the site properties are no longer an evident aspect of the GI concept. This may affect urban development on two scales; the site planning scale (where the significance of existing green space might be overlooked) and the comprehensive planning scale (where the GI tends to be separated from the urban landscape as a whole). GI has, in some European countries, been launched as a planning tool on national level, although with different meanings [13]. In Sweden, the national launch of the GI concept is performed on a regional level, where urban planning is very superficially considered, and GI is therefore discussed as ecological core areas in the countryside and its effects on forestry (Sweden being a forested country) [14]. This apparent confusion about what the concept of GI represents-between different sectors, scales and realms, all crucial for the implementation of GI-is the point of departure for this essay, with the aim of displaying and discussing the need to (1) consider the entire urban landscape and not only public green space; (2) understand the variety of actors/stakeholders and their land use interests and (3) develop appropriate representations of the urban landscape which do not counteract conceptions of GI, but help to clarify the prevalence of GI (in terms of green areas and linkages) as well as areas and paths considered public space, which only partly overlaps GI space.

The underlying idea here is that within the context of sustainable urban development, the very multivalence of the concept of GI has prevented it from being realized and implemented to its full potential.

To actually deliver its ecosystem services, GI not only needs to be programmed in space and time, not only structured in relevant scales, its land use and values deliberated and negotiated horizontally and vertically; it also need continuous links of knowledge and engagement, between actual people with different duties, responsibilities and aspirations. Therefore, the representations and GI programs must be not only transdisciplinary but also publically legible, to facilitate broad collaboration including citizen participation.

\section{Implementing GI in an Existing Urban Landscape-an Emerging Discourse}

The core line of the discourse on urban green and GI has deviated over the years from "benefits of green space" to "ecosystem services". Twenty years ago, in the mid-1990s, "green structure" was a new topic for discussion. The "urban green issue" had been simultaneously growing in many European countries in the 1980s and 1990s, along with the prevalent mission to heed the significance of green areas, albeit with varying outcomes in different national contexts. In 2000-2005 a COST Action, ("Green Structure and Urban Planning"; 50 scholars from 15 countries) met in workshops and seminars and performed case studies to investigate the preconditions, success factors and problems involved in green structures connected with urban planning [6]. This overlapped with and was followed by other similar European initiatives, enduring networks as well as conferences and workshops. 
These transdisciplinary activities complemented a growing research on urban green structures, often connected to departments of landscape planning [15,16], but more recently also in interdisciplinary settings, in a sustainability context [17].

Some years later, Ian Mell, and others completed the palette of conceptual gradients and terminology useful for deepening and broadening the understanding of the scholarly discourse in Europe [4]. In U.S.A., 2006, Anthony Walmsley had updated, completed and contextualized the North American discourse development, and changed the term "greenways" into GI [18]. While much of the previous writing drew on case studies, Mell worked at a general level with a broad spatial and temporal scope. He also addressed the status of green within the stiffening competition for urban space, following the "compact city" concept. GI has slowly shifted point of gravity from "a source providing benefits and recreation areas" to "an infrastructure for ecosystem services". This could (but does not have to) incline a shift from a spatial understanding of GI, to a technical/functional understanding of GI.

GI as a concept is ambivalent and ambiguous. GI as everyday reality is not. It is what it is, in every single situation, not often working as an entirety, but as parts, connected to other kinds of structures. The conceptual development is displayed in both the change of name (from green structure and green ways to green infrastructure, see Table 1) and change in labelling the functions (from benefits of green to ecosystem services).

Table 1. Hits on Google Scholar in 5-year-periods for three concepts used to represent "green" parts of the urban landscape more or less in the same way. In Europe "green structure" have been much used, but has been outstepped by GI after the millennium shift, while "green infrastructure" since then has increased much faster in frequency. Before 2010 "greenways" is the most common word in the U.S., but is now outpaced by GI.

\begin{tabular}{cccc}
\hline & $\begin{array}{c}\text { Urban “Green } \\
\text { Structure" }\end{array}$ & $\begin{array}{c}\text { Urban } \\
\text { “Greenways" }\end{array}$ & $\begin{array}{c}\text { Urban “Green } \\
\text { Infrastructure" }\end{array}$ \\
\hline $1990-1995$ & 40 & 411 & 61 \\
$1995-2000$ & 77 & 1050 & 158 \\
$2000-2005$ & 308 & 2200 & 805 \\
$2005-2010$ & 758 & 3930 & 3840 \\
$2010-2015$ & 1310 & 5540 & 13,300 \\
\hline
\end{tabular}

What actually happens (what is implemented as GI in the urban landscape) depends on whether this takes place as part of a strategic planning dialogue, a political decision affecting property management or a development plan process. Different choices will be made, resulting in GI and ecosystem services of various kinds:

In the future, a combined GI and ES approach could be further developed into an innovative planning concept that captures the complexity and dynamic of social-ecological systems in urban areas and supports policy objectives such as sustainable development, environmental justice, social cohesion, or resilience [1] (p. 527).

While other kinds of infrastructure, such as road systems and water systems, have always been adjusted to an existing urban landscape, as aspects of a continuous modernizing project, the GI concept seems to be more problematic to accept (within urban politics, management and administration). Why? One aspect of significance could be that while other structures (e.g., a pipe system for drinking water) are self-contained (and could as such theoretically function outside of the urban landscape) a GI is not. Its parts are (always) also parts of the urban landscape, but not all parts of the urban landscape are parts of the GI. To implement GI does not mean to construct an entirely new structure, but to enhance and connect already existing green spaces, together with building in-between linkages and take measures to increase biological functions and ES. It might be necessary to clarify, in land use 
discussions, that not only has the GI to be adjusted to the urban landscape, but the urban landscape may also have to be adjusted, in order to establish a GI with capacity to deliver the requested ES.

\section{GI Implemented by Actors and Institutions, in Different Sectors and Scales}

Jack Ahern [19] points at a difference between inert institutional routines and site specific constellations' judgments, in terms of resilience:

When a major urban function or service is provided by a centralized entity or infrastructure, it is more vulnerable to failure. When the same function is provided by a distributed or decentralized system, it is more resilient to disturbance [19] (p. 342).

While GI implies an overall structure and a connective system, it becomes in fact an interface between holistic views like "the city" or "the urban landscape" on the one hand and site-specific ecologies on the other. In its full implementation, a GI would mean an entire system of connected spaces (within an urban area or a region), where each space is allowed to unfold and enrich its ES, according to long term management. Although this should be possible, this is not how we see ES implemented today, in comprehensive and development plans, and this is where we leave the realms of urban ecology and landscape architecture, and enter the field of land ownership and real estate development. It is not until we fully understand the significance of the actions connected to land ownership in the context of urban ecology that we can really test out how to implement far-reaching GI programs. GI projects carried through [6] have most often been made possible on public land, e.g., municipally owned. In a densifying trend, it is not likely that public space will be available for land use change to the same extent that it has been (and where most published examples of successful green structure implementations have been made).

Moreover, the inherent multifunctionality and attractiveness of the GI concept is not possible to implement by one professional sector alone, but requires access to knowledge not only about existing and planned urban structures (planning departments), but also about the physical and functional links between urban GI and the peri-urban and rural landscape (environmental departments), as well as about the management and maintenance of public green space (park departments). Furthermore, the measures and means to actualize GI are most often differently distributed between different kinds of landowners $[1,3,4]$. The way public services are organized (still sectorial) is an obstacle to cross-sectorial collaboration for sustainable urban development [20] but is also hindering complex, multiscale and multipurpose projects like GI development. On the other hand, a municipal organization as a whole is a container of multifarious data, analyses, knowledge and know-how, existing in, but sorted and distributed among different departments. To go from availability to action, a certain level of engagement is needed to collect all this input to a common whole, into trans-disciplinary action-oriented programs. From the evolvement of GI benefits/ecosystem services over time it follows that the concept is not only theoretically interdisciplinary, but also professionally cross-sectional, involving municipal administration and management, planning routines, political undertakings and citizen participation. Throughout Europe, neoliberalism has led to more complex (and complicated) management of public resources, and the authorities' power is being replaced by new power groupings, public-private management, business models, and innovative triple-helix (public-private-academic) projects [21]. Theoretical as well as multifunctional aesthetically appealing models for GI remain highly valuable [1]. But when it comes to implementing them in real-life urban situations, methods are still insufficient to deal with complex situations and site specifics. Even if policy documents are aiming for "a holistic understanding" [22] there are strong organizational structures, often locally specific [23] which do not support such changes in understanding GI. The joint quest for interdisciplinary research on many urban development issues [2,24-26] has not yet reached far enough to support application of GI knowledge to physical, spatial structures in real urban settings. This involves both linking of sectors and hierarchical layers, as well as introduction of necessary administrative and planning routines to make use of available know-how. There are experts with an interdisciplinary culture of 
knowledge; with understanding of e.g., scale-zooming and time-continuity [27]. But bringing more external expertise into planning is no guarantee that this knowledge culture will genuinely exert more influence on planning and development. Sectorial mindsets in the municipal and regional administrative apparatus cannot change overnight, or even in a decade [27].

In contrast to buildings or transport infrastructure, GI has a "maturation period" that seems hard to acknowledge in, for example, urban planning routines, but may arise as a crucial factor in larger-scale implementation of green structure initiatives. While materializing GI (lay-out and planting) is a rapid process compared with buildings and transport infrastructure, fulfilling the aims of green infrastructures is by far a longer process, during which different actors are responsible and during which the very conditions for the delivering of ecosystems services might change. The strength and potential of the concept of GI may lie in its being more than the sum of its parts. To its living components and the constantly new threats facing them, is also attached an ever pending need for cooperation among different public administrative units and between public and private stakeholders in urban development. If successful, a side-effect from an implementation of the GI concept may actually be methods of collaboration, applicable to sustainable urban development in a wider sense as well. If rightly acknowledged, the maturation period could offer also opportunities for long term collaborative approaches.

Recently published articles stress the close relationship between GI and ecosystem services [2,28], but also make evident that (1) the ecosystem services resulting from GI are not necessarily identical with its potential benefits and (2) that applying knowledge of GI and ecosystem services often fails. This failure is due not to insufficient knowledge of how to achieve GI and the desired ecosystem services, but rather to systems and frameworks for planning and management of the urban landscape that are apparently incapable of taking into account these previously ignored qualities. When Patsy Healey describes the contemporary challenges for planning theory (29), she is pointing at "The Coevolution of Place Quality and Governance Capacity" as necessary to have in mind, not just in general, but from a site specific perspective:

Both what are valued as "good" place qualities and "better" ways of doing governance work to promote their realization are rooted in specific histories and geographies [29] (p. 4).

Municipal strategic planning includes the responsibility to take into consideration all land throughout the municipal domain; in this respect, the local government authority overviews urban landscape change. This is not to say that the municipality has the power or jurisdiction to effectuate changes on all land. On the contrary, this power is distributed among the landowners, one of which is the municipality. Property patterns are specific to each city and municipality, and all landowners bear responsibility for their own property management. Overall, this responsibility for land management (including property development) covers the same area as municipal strategic planning, but is divided among a number of stakeholders or landowners.

Figure 1 identifies two different ways in which the urban landscape in its entirety is handled, one superficial and one fragmented. As for actual property development there is collaboration between the public and the private spheres. This results in a development plan followed by building projects. These projects may vary in size but, as a rule, only the specific building sites are concerned. Planning theorists have pejoratively termed this "stamp planning", implying that the projects leave the context out of consideration and disregard both how the surroundings will influence the new project and what impact the project will have on its surroundings [30].

Every year, urbanized areas (with sealed soil, i.e., covered with impermeable surfaces like asphalt or concrete) in Europe are expanding, even in cities with declining populations [31]. This is not an effect of "planning", in the sense of responsible and deliberate implementation of development plans but, as the statistics show, of "the tyranny of small decisions" [32] and the related "tragedy of the commons" [33]. These small and individualized decisions are largely out of reach for today's planning activities designed to facilitate new urban development. If one homeowner chooses to pave 
over a garden, the rest of the city is unaffected. If hundreds of others follow suit, the whole city has a storm water problem [34,35].

\section{STRATEGIC MUNICIPAL DISCUSSIONS AND COMPREHENSIVE PLANS}

\section{PROPERTY MANAGEMENT AND RESPONSIBILITY}

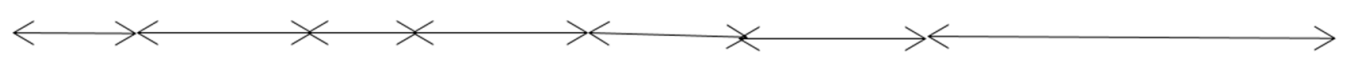

\section{DEVELOPMENT PLANNING PROJECTS}

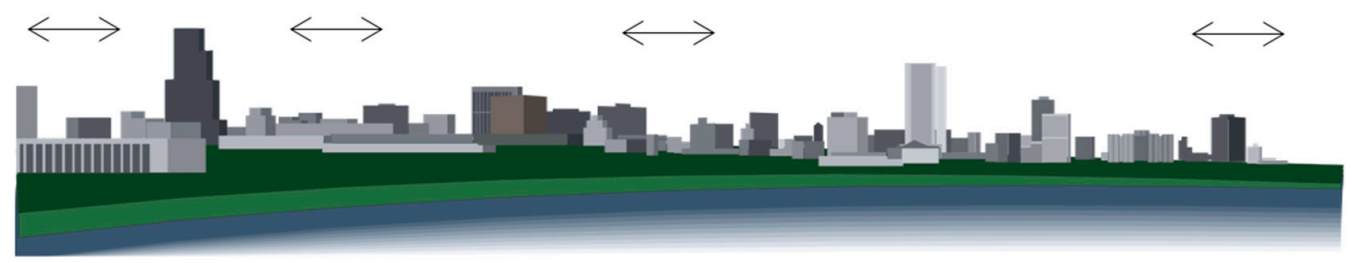

Figure 1. There are different outreaches of responsibility for different actors in the urban landscape. Based on the Swedish Plan and Building Act, comprehensive plans should encompass all land within the municipal borders, but they are not legally binding. Development plans are binding, but covers one or few building blocks at a time. After completed planning project, the property owner is responsible for the management of the site. Together, all property owners have the responsibility for the whole area within the municipality, but there is no forum for land management as a whole.

Distinguishing among different aims and values connected with biological growth, biodiversity, natural areas, well-managed gardens, parks and street trees, whether located in structured or haphazard ways, it need to be taken into account both public and private green urban spaces. Accordingly, to politicize GI planning, in order to make it a superior cross-sectorial task, the implications of ownership in terms of the functions and values of urban GI need to be understood. Here, "politicize" means to fully understand a situation and its preconditions, and to initiate discussion of the "why" and "where" questions before "technification", i.e., the "what" and "how" questions "close the case" [36].

To date, discourses on urban greening, green structuring and green planning have largely relied on technical arguments, which have thus been used to "close the case". This often successful strategy for getting things done has the side-effect of covering problems associated with the prevailing combination of densification and greening, which undoubtedly diminishes the number of benefits achieved. To counteract this side-effect, one needs to step back to the "why" questions about GI and politicize them, analyze the situation and prioritize accordingly, with more or less transparent motives. Such "strategic navigation" [37] cannot be delimited to a separated GI, but has to consider the consequences in the urban landscape as a whole. Even if shared ownership of the implementation of GI is a central theme in this context, the responsibility for overarching strategies and policies will no doubt remain in the hands of local authorities, most often a municipality. Among the strategic choices (and local authorities' responsibilities) for GI is also the issue of distribution of urban green [7,38], an issue nearly related to the distribution of land ownership. Contextual preconditions for creating, changing or adding to the GI in public urban land are very different from those in private urban land. As a matter of fact, the discourse on GI is connected to public space, to the extent that GI benefits and ecosystem services are sometimes confused with urban functions that do not require green elements at all (such as market places or public arenas). In an urban landscape the boundaries between different landowners might not always be of significance, e.g., to a diversity of ecological functions [38]. When implementing a GI, however, these boundaries are important to consider, in order to be able to keep 
the same diversity of ecological functions. This is not the same as saying that authorities should control all land. It is to say that the responsibility for GI must be shared in a transparent and affectable way.

\section{GI Representation and Communication, in a World of Increased Collaboration and Participation}

An apparent increase of "evidence based planning" [39] is not equivalent with planning systems having increased capacity to deal with new knowledge, but could instead be a sign of the increased need to brand choices and decisions [6]. This branding does not signify any change in planning practice, in terms of including research and or evaluations of decisions and strategies. On the contrary, diminished resources for public services seem to restrain planning practice to implementation of regulations, with less (if any) application of evidence and less deliberation between the general and the specific [40].

To operationalize the site-specific and contextual conditions for implementation of a GI policy, GI as expressed in material, technical, spatial and functional terms must be supplemented with representational links to planning processes and routines. "Ecosystems services", as a concept, are a step in this direction. This term makes it possible to label the specific services concerned and investigate the requirements, conditions and resources for implementing GI for these services.

The GI concept is meant to be implemented as a real urban environment. Until it is, however, it has been talked of and depicted as words and pictures. The linguistic as well as the visual representations shape our ideas of what is going to be implemented and affect our ways of doing it. Does it make any difference then, whether we call the effects of GI "benefits of urban green" or "ecosystem services"? If the label "ecosystem services" leads to more concrete thinking when GI is implemented to provide certain services, this may be the case. However, this does not prevent deliberately vague use of either of these concepts in policy documents and political discussions. The clarity of a concept lies not in the word or label itself, but in whether there is an intention to make clear what the concept means, what effects it is planned to have, and by what means and through which stakeholders it is meant to be implemented and sustained.

While there is a long line of optimistic green structure researchers from three decades, Mick Lennon [41,42] scrutinizes the evolving GI discourse from a more critical point of view. As he points out, the idea is hard to grasp and concretize in general terms, and thus not always successful in getting what it represents established as a concept with sufficient properties. On the contrary, in Lennon's examples, the concept of GI seems to represent a limited professional agenda or even serve as an attractive accessory to a political program [41].

Lennon appears to think that the concept of GI (before implementation, my comment) does not clearly represent anything but itself; it remains "a representation of a representation of a representation" [43]. The concept refers to no specific "reality", but is defined according to its status in certain discourses. From a communicative point of view this is certainly devastating, since a self-referring concept has no validity or recognition outside academic or professional discourses.

The problem is not the representational concept per se. We often see, in e.g., the physics that concepts are worked with and handled as realities, long before they are possible to detect as materialities. In the case of GI, however, we are neither discussing microscopic or long-distance objects, nor expanding virtual realities, but are affecting human's everyday environment. Therefore, we have to take into consideration that much of the material, perceivable and ecologically effective properties of GI are just taken for granted and not mentioned. The diagram below (Figure 2) could be used as a frame for a collaborative discussion, between e.g., professionals, politicians and citizens. It is understandable without pre-knowledge and makes possible to have a versatile discussion about in what way different kinds of spaces are affected, if new kinds of spaces are introduced and about who owns the question and who are responsible.

There are numerous examples of confusion between "urban public space" and "urban greenery". In green policy documents, "green structure" is most often confined to public green space. Mapping of 
any European city will show, however, that this makes sense neither quantitatively nor qualitatively if we want congruence between the language and visual representations of the urban environment, on the one hand, and what we as urban citizens experience as such on the other. While most urban public space consists of roads and car parks, most urban greenery is (still) located in gardens and other private space. The existence of an important overlap does not logically allow these categories to be labelled as one. Especially concerning ecosystem services, it is crucial to understand urban space in terms not only of material, form and function, but also of who is responsible for managing and organizing development in each area, including both day-to-day maintenance and long-term decisions and conditions (see Figure 1).

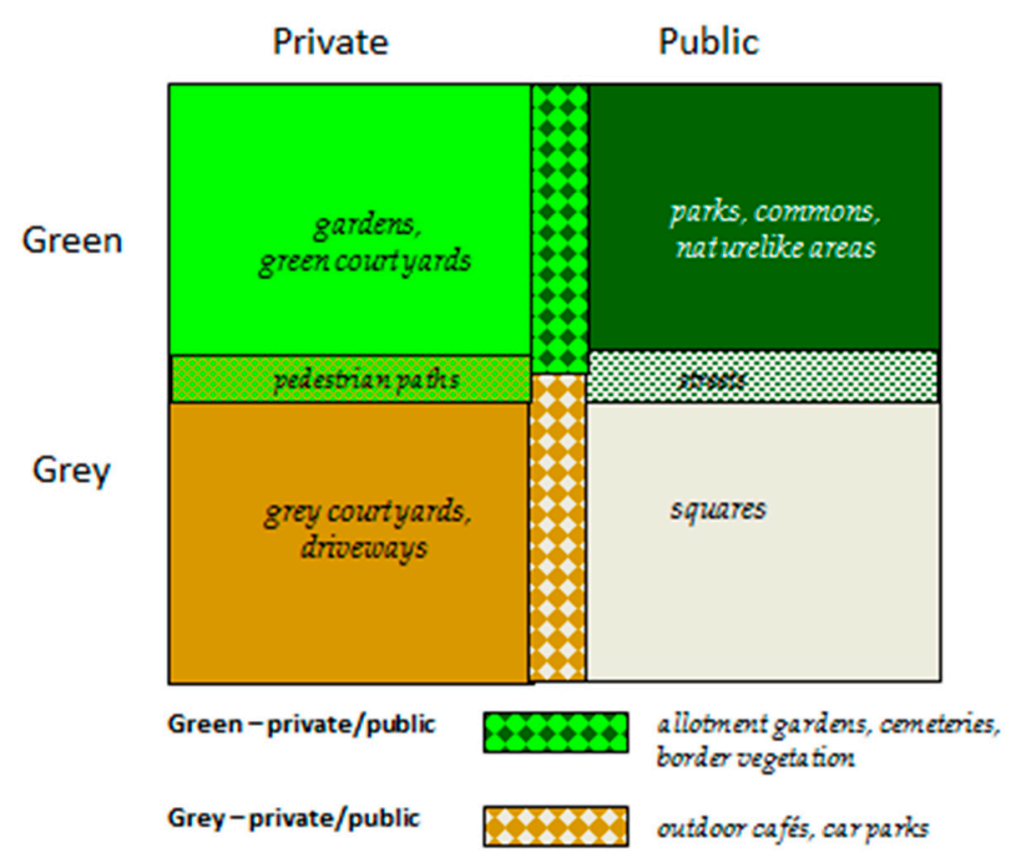

Figure 2. GI concerns both private and public areas. Urban public space is both green and non-green ("gray"). Urban green public space is a fraction of both. By combining the private-public and the green-gray dimensions a typology appears which take into account spatial and material properties as well as the property of ownership and it also becomes visible that there are types of space linked to both dichotomies but in different ways.

If we want to understand urban space in a full dynamic sense, in relation to specific situations, it is also essential for our representations of urban space-maps, plans and information-to be aligned with the purpose of meeting any conditions of relevance and concern. To date, urban maps and plans have not shown GI in a way that is useful in terms of maximizing their potential benefits; instead, they display the difference between "formal green structure" and "actual green structure" [7]. Accordingly, conventional mapping of the urban landscape may be said to thwart any clarification of green structure concepts (Figure 3).

On the other hand, critically analyzed, the same maps can also reveal some aspects taken for granted. One that is ubiquitous but neither acknowledged nor questioned in city maps is the private ownership of green resources (city maps are not similar everywhere, but I have not yet found, in spite of searching for decades, a printed map consequently displaying both ownership and greenery). Blocks used for residential or business purposes are marked with the same color, regardless of ownership and the amount of greenery. Instead, maps follow the labels used in planning processes for public green space. Thus, space under municipal management is painted green regardless of what kind of greenery it contains, while a residential block can be surrounded by extensive greenery without showing as green on a map. Arguably, this is insignificant now that we can use GPS and satellite pictures instead 
of maps for navigation. The point is not, however, how our surroundings are perceived from the ground (which is unaffected) but how the ground is perceived from maps, in professional planning work and regulated communication between planning authorities and citizens. Whatever advantages the current way of mapping cities may have, it is not conducive to GI innovation or implementation.

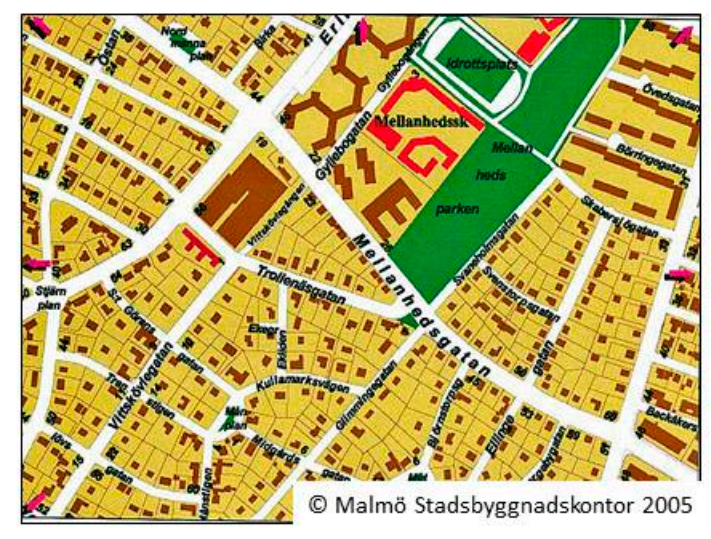

(a)

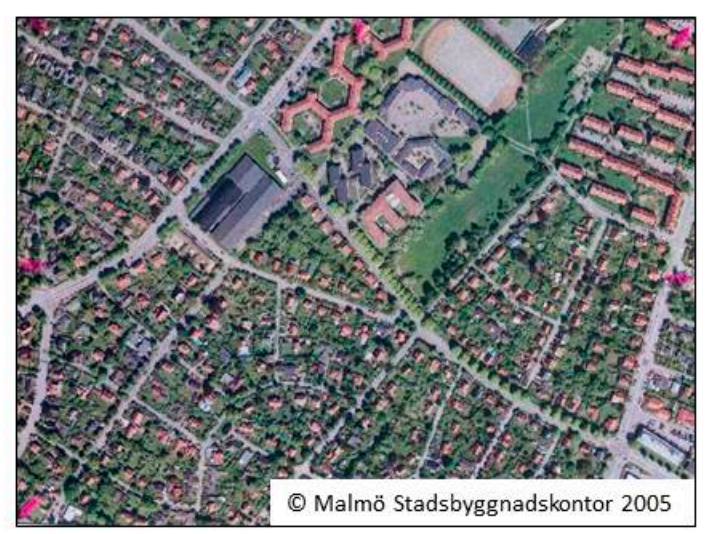

(b)

Figure 3. The standard way habit of representing "municipal green" with the green color, while privately owned land is represented with any color regardless of land use (a), confuses our conceptualization of the urban landscape. The quite considerable amount of private green space (b) is therefore not counted as a common asset, which affects the work on ecosystem services.

To date, there have been no strong regulations on the design of private gardens for sustainable purposes or recommendations about the management and maintenance of private land for such purposes. In short (see, however, [12,34]), literature on GI and urban greening fails to sufficiently discuss the principal implications of these structures that, in contrast to other urban structures, do not prevail in shape, materiality, functions or effects (and consequently do not result in the same perceptions and experiences over time), regardless of management.

Susanna Gill and others have convincingly shown the significance of private gardens in terms of urban water balance [34]. A considerable risk is posed by the trend of paving gardens with impermeable materials. Thus, private ownership and how its relationship with public needs is negotiated is of the utmost relevance in a discussion of green structure for urban water resilience.

Representations of the urban landscape are closely linked to legal and institutional structures and vital for implementation of GI. Being national, regional and local, these structures are easily overlooked in international research fora. The importance (and neglect) of institutional preconditions for linking theory and practice has been pointed out in case studies [3,12]. Roe and Mell have even described the situation as "institutional schizophrenia" [3] (p. 650) and argued that, in the UK, there appears to be a mismatch between the policy aims and the potential for creating GI on the ground through collaborative stakeholder decision-making [3] (p. 669) They seem to be referring to a reality entirely opposed to what was claimed in the ESDP in 1999 as decisive for the future: horizontal as well as vertical cooperation [44] (p. 36).

\section{Conclusions}

The paper has argued that GI implementation means considering GI in relation to the entire urban landscape, that GI implementation is carried through by many actors, in need of different kinds of encouragement, resources and tools, and that GI implementation demands facilitation by means of urban landscape representations, within which GI is depicted both as a system/structure/network and as geographically correct spatialities. There is unequivocal evidence for multiple benefits from urban green [1-5]. These are thought to include increased biodiversity, a better capacity for storm water 
management, a reduced urban heat island effect, healthier air conditions (less dust, more humidity), a more salubrious living environment and improved characteristics of public meeting places.

There is also, however, a persistent gap between the benefits of a generalized "urban green" and the expectations of effects when implementing GI in a specific context [45]. The effects cannot materialize regardless of (a) the nature of conditions before the GI project; (b) how well the project is adapted to the local context and site-specific factors; or (c) long-term visions, maintenance requirements and adaptation potential. Another question that is commonly omitted is whether the new structure will fulfil its function immediately or whether the anticipated result is attainable only when there is a certain volume of biomass or foliage, or degree of biodiversity, has been achieved.

This article contributes by adding to the necessary critical thinking around how GI can be implemented, within site-specific circumstances, to accomplish generally approved multiple functions and ES. As well as the specific professional jargons that were previously developed, separating planners, landscape architects, engineers and park managers from each other, we need to create new common, intersectional jargon, about how to achieve urban fabrics with enough green quantities and qualities for the potential benefits as part of the design of developments, but also as part of planning and design of a social infrastructure and as part of an infrastructure for ES. This will not always coincide with a program easily agreed on. Plants will certainly in many cases add to the value of buildings, whereas a public park in the vicinity will not necessarily do so regardless of maintenance. GI could be developed as a means to create a purposive composition of buildings, transport infrastructure and green infrastructure, but whether its potential will be realized depends as much on the way this process is governed as on the potential of GI itself.

The arguments put forward are directed at the fulfilment of the potential of GI and could be understood as suggestions for continued research in three directions, in line with the figures. While the first (Figure 1) touches upon the issues of management in a planning context (and illustrates the problem of "the tyranny of small steps"), the second (Figure 2) concerns the difficulty of separating the two dichotomies "green-gray" and "public-private". The third, (Figure 3) displays the problem with representation of the dichotomies in Figure 2. While the city map is clear about the borders of ownership, it does not show what is green or gray. The satellite picture, on the other hand, is clear on the green-gray distinction (on a canopy level), but does not show the functional and ownership borders visible from the ground. In collaborative GI projects with different kinds of stakeholders, with both public and private interests, possibly also with ambitions to involve citizens without ownership it may be necessary to increase the informative material used, to pair the information with the intentions of the project. In a fictive project in the area shown in Figure 3, both pictures should be used, since none of them is sufficient.

I do not claim that the aspect of linking among functions, resources and stakeholders is new discovery. It is not, and the critique against sectorially based "sustainability research" is growing [46], but since much of the everyday environment is taken for granted, there is more relevant knowledge to be found. The potentially optimal GI is built, not only from knowledge and assets brought to a site or structure, but also from what is already there.

If we leave the scientific and technical domain and enter the everyday world of habitation, property speculation and extreme social complexity, general principles never suffice, but must be adjusted and elaborated on in specific situations. In increasingly complex settings, not least regarding urban development, theorists may have a new role: to keep track of progress in processes formerly seen as sectorial interests, one undoubtedly being GI.

While many ideas that impel action concerning urban green space derive from the public domain, responsibility for launching initiatives and taking action for change lies mainly with landowners, most often private, frequently numerous and both economically and politically diverse. Whether an area is "green" at a certain time is therefore never the sole criterion for the space having certain functions, providing certain benefits and being part of a particular infrastructure. The very potency of change is inseparable from it. 
Figure 2 gives some examples of what may be inserted into a general diagram to measure space in a specific urban area. To understand and elaborate on the dimensions (by, for example, asking what would actually happen if green space increased in relation to grey), one would need to combine the diagram with a GIS and tables of categorized data on the areas measured. So far, to my knowledge, this has not been done. It may therefore be stated that, despite all the promotion of green space in urban areas and the existing consensus on the blessings of creating it, we have not yet attained any certainty on the overall outcomes of these projects, considered as GI, This means that we are not just lacking sufficient examples of GI effects on the urban fabric as an entirety, but also ways of estimating possible side effects [47].

On the other hand, there are some very promising examples of GI implementations being carried out, without a complete theory. There is the All London Green Grid (supported by the city mayor), which establishes aims, strategies and plans that will be implemented one at a time and affect other land owners [48]. There is the Kentucky Green Infrastructure Action Plan [46], which, although only directed at storm water management, provides a way of suggesting actions for landowners while explaining the motives for doing so. Most planning and building laws already impose restrictions on urban development; limiting land use, building height etc. This action plan shows a way to motivate instead of regulate. This approach may be a less time-consuming way to affect the collective of landowners within a city, than taking the long way to legal restrictions and dictates.

For such motivating action plans or programs, new visual representations of GI are needed, not as separate systems in a built-up urban environment, but as integral parts of the urban landscape, understood and managed as such, in collaborative, intersectorial, participatory networks that are yet to be created.

As Figure 3 shows (see also [7]) new visual representations of GI, as part of the urban landscape, are needed in order to support understanding of the potentials and obstacles in GI provision and implementation. This is needed for more detailed, quantitative relational knowledge on how to weave GI into the urban fabric. This is also needed for urban planning and management purposes, in order to provide the best foundation for public and private initiatives and negotiations. From the most recent publications on GI [49] and project reports (from the ongoing EU project GREENSURGE) [12], it is obvious that there is no lack of energy or research ambition for the field of implementation of GI. Inclusive representations, however, as important media for collaborative implementation, for understanding of site specific evolvement of GI, are still missing in the discourse. "Thick" [50] representations of GI will be necessary, not only to promote implementation of GI concepts and the obtainment of benefits for urban life, but also as a reaction to a growing literature accusing GI concepts of "green-washing" financial interests in urban development and of sheer manipulation [51-53].

Acknowledgments: The research behind this article is funded by the Swedish research council Formas and the Swedish University of Agricultural Sciences. The costs to publish in open access are covered by the Department of Urban and Rural Development, Swedish University of Agricultural Sciences.

Conflicts of Interest: The author declares no conflict of interest.

\section{References}

1. Hansen, R.; Pauleit, S. From Multifunctionality to Multiple Ecosystem Services? A Conceptual Framework for Multifunctionality in Green Infrastructure Planning for Urban Areas. Ambio 2014, 43, 516-529. [CrossRef] [PubMed]

2. Andersson, E.; Barthel, S.; Borgström, S.; Colding, J.; Elmqvist, T.; Folke, C.; Gren, A. Reconnecting Cities to the Biosphere: Stewardship of Green Infrastructure and Urban Ecosystem Services. Ambio 2014, 43, 445-453. [CrossRef] [PubMed]

3. Roe, M.; Mell, I. Negotiating value and priorities: Evaluating the demands of green infrastructure development. J. Environ. Plan. Manag. 2013, 56, 650-673. [CrossRef]

4. Mell, I. Green Infrastructure: Concepts, Perceptions and Its Use in Spatial Planning. Ph.D. Thesis, Newcastle University, Newcastle, UK, 2010. 
5. Ahern, J. Green infrastructure for cities: The spatial dimension. In Cities of the Future: Towards Integrated Sustainable Water and Landscape Management; Novotny, V., Brown, P., Eds.; IWA Publishing: London, UK, 2007.

6. Werquin, A.C.; Duhem, B.; Lindholm, G.; Oppermann, B.; Pauleit, S. Green Structures and Urban Planning; COST C11 Final Report; COST: Brussels, Belgium, 2005.

7. Alm, E.L. Visualizing Urban Green Qualities in Sweden: A Way of Raising the Quality of the Urban Landscape. Built Environ. 2003, 29, 306-314. [CrossRef]

8. Lindholm, G. Green structure as activity and as object: Implications for urban planning. Nord. J. Archit. Res. 2002, 15, 41-49.

9. Walmsley, A. Greenways and the making of urban form. Landsc. Urban Plan. 1995, 33, 81-127. [CrossRef]

10. Little, C.E. Greenways for America: Creating the North American Landscape; John Hopkins University Press: Baltimore, MD, USA, 1990.

11. Benedict, M.A.; McMahon, E.T. Green infrastructure: Smart conservation for the 21st Century. Renew. Resour. J. 2002, 20, 12-17.

12. Davies, C.; Hansen, R.; Rall, E.; Pauleit, S.; Lafortezza, R.; De Bellis, Y.; Santos, A.; Tosics, I. The Status of European Green Space Planning and Implementation Based on an Analysis of Selected European City-Regions. Available online: httpp/ / www.greensurge.eu (accessed on 28 March 2017).

13. European Commission. Green Infrastructure Implementation. In Proceedings of the European Commission Conference, Brussels, Belgium, 19 November 2010.

14. Swedish Environmental Protection Agency. Att ta Fram Handlingsplaner för Grön Infrastruktur. 2016. Available online: https://www.naturvardsverket.se/Stod-i-miljoarbetet/Vagledningar/Samhallsplanering/ Gron-infrastruktur/ (accessed on 28 March 2017).

15. Jensen, M.B.; Persson, B.; Guldager, S.; Reeh, U.; Nilsson, K. Green structure and sustainability-Developing a tool for local planning. Landsc. Urban Plan. 2000, 52, 117-133. [CrossRef]

16. Thorén, K.H. "The green poster" A method to evaluate the sustainability of the urban green structure. Environ. Impact Assess. Rev. 2000, 20, 359-371. [CrossRef]

17. Andersson, E. Urban landscapes and sustainable cities. Ecol. Soc. 2006, 11, 34. [CrossRef]

18. Walmsley, A. Greenways: Multiplying and diversifying in the 21st century. Landsc. Urban Plan. 2006, 76, 252-290. [CrossRef]

19. Ahern, J. From fail-safe to safe-to-fail: Sustainability and resilience in the new urban world. Landsc. Urban Plan. 2011, 100, 341-343. [CrossRef]

20. Engström, C.J. Hållbar Stadsutveckling-Hinder och Möjligheter. Sustainable Urban Development-Hindrances and Possibilities. In Sw. Report for the Swedish Governments Delegation for Sustainable Cities, 2008-2012; SOU: Stockholm, Sweden, 2012.

21. Listerborn, C. The flagship concept of the '4th urban environment'. Branding and 557 visioning in Malmö, Sweden. Plan. Theory Pract. 2017, 18, 11-33. [CrossRef]

22. Jansson, M.; Lindgren, T. A review of the concept 'management' in relation to urban landscapes and green spaces: Toward a holistic understanding. Urban For. Urban Green. 2012, 11, 139-145. [CrossRef]

23. Randrup, T.B.; Persson, B. Public green spaces in the Nordic countries: Development of a new strategic management regime. Urban For. Urban Green. 2009, 8, 31-40. [CrossRef]

24. Pickett, S.T.A.; Cadenasso, M.L.; Grove, J.M. Resilient cities: Meaning, models, and metaphor for integrating the ecological, socio-economic, and planning realms. Landsc. Urban Plan. 2004, 69, 369-384. [CrossRef]

25. Diedrich, L.; Kahn, A.; Lindholm, G. Beyond Best Practice: Re-valuing mindsets and models in harbor transformation. Portus Plus Online J. RETE 2016, 6, 1-8.

26. Lindholm, G. 'Visible gestures': On urban landscape perspectives in planning. Plan. Theory 2012, 11, 5-19. [CrossRef]

27. Novotny, H. Transgressive Competence: The Narrative of Expertise. Eur. J. Soc. Theory 2000, 3, 5-21. [CrossRef]

28. Kabischa, N.; Haase, D. Green justice or just green? Provision of urban green spaces in Berlin, Germany. Landsc. Urban Plan. 2014, 122, 129-139. [CrossRef]

29. Healey, P. Planning Theory: The Good City and Its Governance. Int. Encycl. Soc. Behav. Sci. 2015, 18, $202-207$.

30. Burns, C.; Kahn, A. Site Matters: Design Concepts, Histories and Strategies; Routledge: New York, NY, USA, 2005.

31. Nilsson, K.; Pauleit, S.; Bell, S.; Aalbers, C.; Nielsen, T.S. Peri-Urban Futures: Scenarios and Models for Land Use Change in Europe; Springer: Berlin, Germany, 2013. 
32. Kahn, A.E. The tyranny of small decisions: Market failures, imperfections, and the limits of economics. Kyklos 1966, 19, 23-47. [CrossRef]

33. Hardin, G. The tragedy of the commons. Science 1968, 162, 1243-1248. [CrossRef] [PubMed]

34. Gill, S.E.; Handley, J.F.; Ennos, A.R.; Pauleit, S. Adapting Cities for Climate Change: The Role of the Green Infrastructure. Built Environ. 2007, 33, 115-133. [CrossRef]

35. Deak Sjoman, J.; Gill, S.E. Residential runoff-The role of spatial density and surface cover, with a case study in the Höjeå river catchment, southern Sweden. Urban For. Urban Green. 2014, 13, 304-314. [CrossRef]

36. Metzger, J.; Allmendinger, P.; Oosterlynck, S. Planning, Politics, the Political: Complex entanglements and conceptual conundrums. In Proceedings of the AESOP Annual Congress 2014, Utrecht, The Netherlands, 9-12 July 2014.

37. Hillier, J. Strategic navigation across multiple planes: Towards a Deleuzean-inspired methodology for strategic spatial planning. Town Plan. Rev. 2011, 82, 503-552. [CrossRef]

38. Elander, I.; Lundgren-Alm, E.; Malbert, B.; Sandström, U. Biodiversity in Urban Governance and Planning: Examples from Swedish Cities. Plan. Theory Pract. 2005, 6, 283-301. [CrossRef]

39. Davoudi, S. Planning as practice of knowledge. Plan. Theory 2015, 14, 316-331. [CrossRef]

40. Campbell, S. Green Cities, Growing Cities, Just Cities?: Urban Planning and the Contradictions of Sustainable Development. J. Am. Plan. Assoc. 1999, 62, 296-312. [CrossRef]

41. Lennon, M. Green infrastructure and planning policy: A critical assessment. Local Environment. Int. J. Justice Sustain. 2015, 20, 957-980.

42. Lennon, M.; Scott, M. Delivering ecosystem services via spatial planning: Reviewing the possibilities and implications of a green infrastructure approach. Town Plan. Rev. 2014, 85, 563-587. [CrossRef]

43. Baudrillard, J. Simulacra and Simulation; University of Michigan Press: Ann Arbor, MI, USA, 1994.

44. Committee on Spatial Development. ESDP European Spatial Development Perspective: Towards Balanced and Sustainable Development of the Territory of the European Union; European Commission: Potsdam, Germany, 1999.

45. De Block, G. Ecological infrastructure in a critical-historical perspective: From engineering 'social' territory to encoding 'natural' topography. Environ. Plan. A 2016, 48, 367-390. [CrossRef]

46. Watershed Watch in Kentucky, Inc. The Kentucky Green Infrastructure Action Plan. Available online: https://kwalliance.org/wp-content/uploads/2013/01/ky_green_infrstruc_action_plan.pdf (accessed on 28 March 2017).

47. Pataki, D.E.; Carreiro, M.M.; Cherrier, J.; Grulke, N.E.; Jennings, V.; Pincet, S.; Pouyat, R.V.; Whitlow, T.H.; Zipperer, W.C. Coupling biogeochemical cycles in urban environments: Ecosystem services, green solutions, and misconceptions. Front. Ecol. Environ. 2011, 9, 27-36. [CrossRef]

48. The Mayor of London. Green Infrastructure and Open Environments: The All London Green Grid. Supplementary Planning Guidance. Available online: https:/ /www.london.gov.uk/sites/default/files / algg_spg_mar2012.pdf (accessed on 28 March 2017).

49. Mell, I.; Allin, S.; Reimer, M.; Wilker, J. Strategic green infrastructure planning in Germany and the UK: A transnational evaluation of the evolution of urban greening policy and practice. Int. Plan. Stud. 2017. [CrossRef]

50. Latzko-Toth, G.; Bonneau, C.; Millette, M. Small Data, Thick Data: Thickening Strategies for Trace-based Social Media Research. In The SAGE Handbook of Social Media Research Methods; Sloan, L., Quan-Haase, A., Eds.; Sage: Los Angeles, CA, USA, 2016.

51. Kaplan, A. "Green Infrastructure" Concept as an Effective Medium to Manipulating Sustainable Urban Development. In Green and Ecological Technologies for Urban Planning: Creating Smart Cities (Volume in "Regional Development: Concepts, Methodologies, Tools and Applications"); Ercoskun, O.Y., Ed.; IGI Global: Hershey, PA, USA, 2011; pp. 234-255.

52. Lorr, M.J. Defining Urban Sustainability in the Context of North American Cities. Nat. Cult. 2012, 7, 16-30. [CrossRef]

53. Schuetze, T.; Chelleri, L. Urban Sustainability versus Green-Washing-Fallacy and Reality of Urban Regeneration in Downtown Seoul. Sustainability 2016, 8, 33. [CrossRef]

(C) 2017 by the author. Licensee MDPI, Basel, Switzerland. This article is an open access article distributed under the terms and conditions of the Creative Commons Attribution (CC BY) license (http:/ / creativecommons.org/licenses/by/4.0/). 